\title{
A Survey for the Presence of Teichuronic Acid in Walls of Bacillus megaterium and Bacillus cereus
}

\author{
By P. J. WHITE \\ Department of Microbiology, The University, Western Bank, Sheffield S I0 2TN
}

(Received 18 May 1977)

\section{INTRODUCTION}

Teichuronic acids are heteropolymers containing uronic acid and other carbohydrate residues but little (if any) phosphorus; they are present in walls of some Gram-positive bacteria. White \& Gilvarg (1977) isolated a teichuronic acid containing glucuronic acid, rhamnose and glucose from walls of Bacillus megaterium M46. No teichoic acid was present in these walls, whereas Ghuysen, Leyh-Bouille \& Dierickx (1962) found a teichoic acid as a major component of walls of $B$. megaterium KM. Ellwood \& Tempest (1972) showed that this polymer was replaced by a teichuronic acid when strain KM was grown with phosphoruslimitation in a chemostat. Neither teichoic acid (Baddiley, 1968) nor teichuronic acid (see below) are present in walls of $B$. megaterium NCIB758I after growth in batch culture in a simple chemically-defined medium.

In this survey, walls of 10 strains of B. megaterium and two strains of Bacillus cereus have been assayed for uronic acids, rhamnose and phosphorus. Only strain $\mathrm{m} 46$ contained teichuronic acid, and walls of several strains contained neither teichoic nor teichuronic acids.

\section{METHODS}

Organisms. The origins of B. cereus NCIB6349 and NCIB7464, and of B. megaterium KM, 216, NCIB4821, NCIB7581, NCIB8508, NCIB9323, NCIB9376 and ATCC13632 were given by White (1972); B. megaterium KM and $A \operatorname{TCCr} 3632$ are supposedly identical, but are clearly distinct strains (White, 1972). Bacillus megaterium $\mathrm{M}$ was from the Czechoslovak Collection of Micro-organisms, and B. megaterium M46 (a diaminopimelateand lysine-requiring mutant, not derived from strain $\mathbf{M}$ ) was described by Pitel \& Gilvarg (1970). All were maintained on nutrient agar slopes (plus $100 \mu \mathrm{g}$ diaminopimelate $\mathrm{ml}^{-1}$ for $\mathrm{M46}$ ) that were incubated overnight at $37^{\circ} \mathrm{C}$ (30 ${ }^{\circ} \mathrm{C}$ for strain 13632 ), and stored at $2{ }^{\circ} \mathrm{C}$.

Media. Minimal medium A (White, 1972) was used for B. megaterium м, км, 2 16, 8508 and 9323. Supplements for $B$. megaterium 7581 and 9376 , and for $B$. cereus 6349 and 7464 are listed by Day \& White (1977). Supplements for other strains of $B$. megaterium were (in $\mathrm{mg}^{-1}$ ): L-glutamic acid ( 120 ) and L-leucine (60) for 13632; L-asparagine (400), L-glutamic acid (200) and L-proline (100) for 4821 ; and diaminopimelic acid (100) and L-lysine hydrochloride (50) for M46. Medium AI contained $1 \%$ (w/v) glycerol and medium A2 contained I \% $(w / v)$ glucose.

To restrict growth of $B$. megaterium $758 \mathrm{I}$ by limitation of inorganic orthophosphate, the basal solution of medium A was modified to contain $\left(1^{-1}\right): N$-2-hydroxyethylpiperazine- $N^{\prime}$-2-ethanesulphonic acid (HEPES), $10 \mathrm{mmol}$; $3-\left(N\right.$-morpholino)propanesulphonic acid (MOPS), $10 \mathrm{mmol}$; piperazine- $N, N^{\prime}$-bis(2-ethanesulphonic acid) (PIPES), $10 \mathrm{mmol}$; $\left(\mathrm{NH}_{4}\right)_{2} \mathrm{SO}_{4}, 2 \mathrm{~g} ; \mathrm{KCl}, 20 \mathrm{mmol}, \mathrm{KH}_{2} \mathrm{PO}_{4}, 0.5 \mathrm{mmol}$; trisodium citrate. $2 \mathrm{H}_{2} \mathrm{O}, 20 \mathrm{mg}$; biotin, $0.2 \mu \mathrm{g}$; the $\mathrm{pH}$ value was adjusted to 7.2 with $\mathrm{NaOH}$. These ingredients were autoclaved together (at about I.25 times working strength); after cooling, glucose and salts of $\mathbf{M g}^{2+}, \mathrm{Fe}^{2+}$ and $\mathrm{Mn}^{2+}$ were added, as for medium A2 (White, 1972).

Growth of organisms and isolation of walls. Batch cultures were grown in conical flasks and walls were isolated after breaking the organisms in the pressure cell of Milner, Lawrence \& French (1950), as described by Day \& White (1977).

Chromatography. Walls were hydrolysed in sealed tubes with $2 \mathrm{M}-\mathrm{HCl}$ at $100{ }^{\circ} \mathrm{C}$ for I $\mathrm{h}$ (to release monosaccharides) or with $6 \mathrm{M}-\mathrm{HCl}$ at $105^{\circ} \mathrm{C}$ for $18 \mathrm{~h}$ (to release diaminopimelate). Hydrochloric acid was removed by repeatedly drying the hydrolysates in a desiccator. Descending chromatograms were run on 
Whatman no. I paper at room temperature. Solvent I was ethyl acetate/acetic acid/water (9:2:2, by vol.); solvent 2 was butan-I-ol/pyridine/water (6:4:3, by vol.); and solvent 3 (Rhuland et al., 1955) was methanol/ pyridine/ $\mathrm{IO} \mathrm{M}-\mathrm{HCl} /$ water $(32: 4: \mathrm{I}: 7$, by vol.). Carbohydrates were detected with $p$-anisidine reagent (Bailey, 1969) and amino acids with ninhydrin, as described by Day \& White (1977).

Assays. The phenol/sulphuric acid method of Dubois et al. (1956) and the modified anthrone reagent method of Herbert, Phipps \& Strange (1971) were used to measure carbohydrate in walls. In the former assay, I $\mathrm{ml}$ of $5 \%(\mathrm{w} / \mathrm{v})$ phenol was always used per tube, and glucose was the standard for both methods. Uronic acids were determined by the assay of Bitter \& Muir (1962), with glucuronic acid as standard. Rhamnose was measured by the method of Dische \& Shettles (1948). Phosphorus was measured as described by Ames (1966); all samples (test and standard) were ashed with magnesium nitrate before assay to convert organic phosphorus to inorganic orthophosphate. Diaminopimelate was assayed by the method of Work (1957) in which acidic ninhydrin is used at $37^{\circ} \mathrm{C}$.

Bacteriological tests. Bacillus megaterium M46 was examined using the methods listed by White (1972), except that the procedure of Conn, Jennison \& Weeks (1957) with $0.3 \%$ (w/v) creatine in the $\mathrm{KOH}$ solution was used for the Voges-Proskauer test. Diaminopimelic acid $\left(100 \mu \mathrm{g} \mathrm{ml}^{-1}\right)$ was added to all the crude media. Incubations were at $37{ }^{\circ} \mathrm{C}$ except for stab cultures in nutrient broth (Oxoid) containing $5 \%$ (w/v) gelatine (and diaminopimelate), which were incubated at room temperature. Spores of strain m46 were produced at $30{ }^{\circ} \mathrm{C}$ in medium A containing $0.1 \%(\mathrm{w} / \mathrm{v})$ glucose, diaminopimelate $\left(100 \mu \mathrm{g} \mathrm{ml}^{-1}\right)$ and L-lysine hydrochloride $\left(20 \mu \mathrm{g} \mathrm{m}^{-1}\right)$, by addition of dipicolinic acid and $\mathrm{CaCl}_{2}$ (both to $\mathrm{I} \mathrm{mM}$ final concentration) at the end of exponential growth (Pitel \& Gilvarg, 1970).

Chemicals. Diaminopimelic acid was a mixture of all three isomers, synthesized as described by Saleh \& White (1976). HEPES, MOPS and PIPES were from Sigma.

\section{RESULTS AND DISCUSSION}

Of the organisms grown in batch culture in medium A, only B. megaterium M46 contained more than traces of uronic acid and rhamnose in its wall (Table 1 ). However, this strain does seem, in other respects, to have the properties expected of the species $B$. megaterium (Buchanan \& Gibbons, 1974; White, 1972). The organisms were Gram-variable rods, about $\mathrm{I} \cdot 5 \mu \mathrm{m}$ wide and 3 to $5 \mu \mathrm{m}$ long, growing in chains of a few organisms, and very sluggishly motile in medium $\mathrm{A}$ at $30^{\circ} \mathrm{C}$. They were catalase-positive and formed terminal or subterminal, oval to spherical spores; the sporangia were not swollen by the spores. Gelatine was liquefied in 2 to 3 days, and starch was hydrolysed. There was no anaerobic growth [in $\mathrm{N}_{2} / \mathrm{CO}_{2}(95: 5, \mathrm{v} / \mathrm{v})$ ] within 3 days at $37^{\circ} \mathrm{C}$ in glucose/nutrient broth or on glucose/ nutrient agar, though aerobically these media allowed heavy rapid growth of highly vacuolated organisms. The lecithinase and Voges-Proskauer tests were negative. Acid but no gas was produced from glucose, mannitol and arabinose, but not from xylose. No growth factors were required other than diaminopimelate and lysine, the requirements for which were deliberately imposed by mutation (Pitel \& Gilvarg, 1970). Unfortunately, the wild-type parent strain of $\mathrm{m} 46$ was not available, hence the inclusion of teichuronic acid by 446 could be the result of an additional mutation that occurred while the blocks in the biosynthesis of diaminopimelate and lysine were being imposed.

The teichuronic acid of strain M46 was first recognized in organisms grown at $32{ }^{\circ} \mathrm{C}$ with glucose as main carbon source, and then treated with detergent and enzymes (White \& Gilvarg, I 977). The walls of other strains now examined were isolated mostly from organisms grown at $37^{\circ} \mathrm{C}$ with glycerol, and broken by shearing forces. However, walls of strain $\mathrm{M} 46$ still contained teichuronic acid after growth with glycerol at $37^{\circ} \mathrm{C}$ or at $30^{\circ} \mathrm{C}$, followed by breakage of the bacteria in the pressure cell. Furthermore, strain $758 \mathrm{I}$ did not form a teichuronic acid when grown with glucose at 30 or $37^{\circ} \mathrm{C}$ (Table I).

In the modified medium A2 with limited phosphate, growth of strain 758 I stopped when the yield of organisms was about I mg dry wt ml-1. With I mM- $\mathrm{KH}_{2} \mathrm{PO}_{4}$ (or higher concentrations), growth in the modified medium was as heavy and rapid as in ordinary medium A2. After growth with restricted phosphate, walls of strain 758I contained more anthronepositive material than was found after growth with glucose and excess phosphate, and some uronic acid was found by assay, though no uronic acid spot was identified on chromato- 


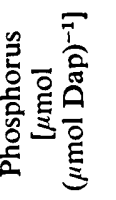

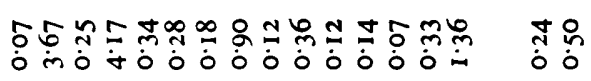

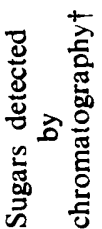

క్

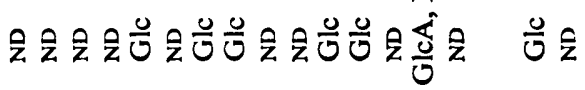

$\frac{0}{0}$

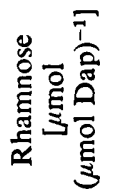

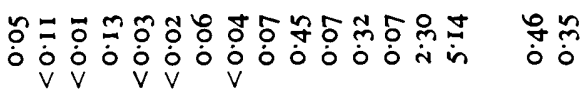

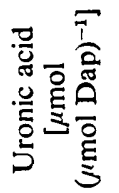

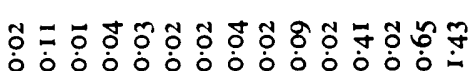

ồ

岁

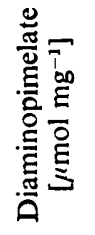

боำ

寄

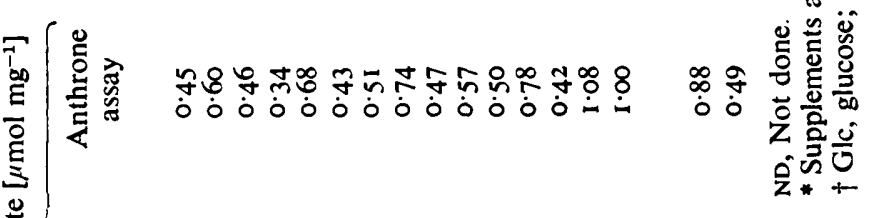

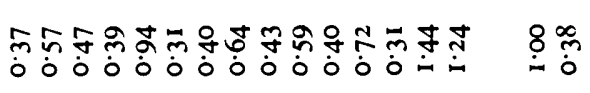

क

용

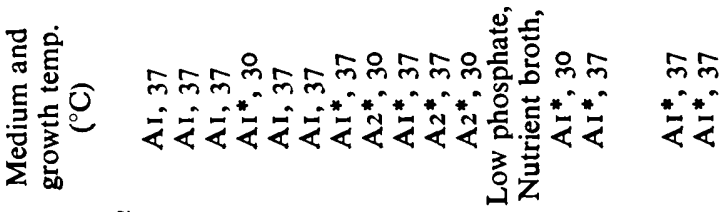

紊 
grams (Table I). In a batch culture, only the organisms that are still growing when the culture approaches the stationary phase will really be phosphate-limited, and so the walls isolated in the present study are not strictly comparable with walls of phosphate-limited organisms from a chemostat.

In no walls, except those of M46 (which are known to contain rhamnose and glucuronic acid) and 8508 , was there a large excess of total carbohydrate (measured with phenol/ sulphuric acid) over anthrone-positive material, which is largely hexose (Herbert et al., 1971). Glucose was the only hexose that could be identified clearly in more than traces on paper chromatograms (solvents I and 2). Whether glucose is really part of the wall structure, or whether it is derived from trapped granules of a glycogen-like polymer (cf. White \& Gilvarg, 1977) has not been established. Rhamnose and glucuronic acid (or its lactone) were not detected in hydrolysates of any wall except strain $\mathbf{M 4 6}$, where they were obvious.

Diaminopimelate was assayed in most of the walls, to assess roughly their content of peptidoglycan. If, for every I mol diaminopimelate, $2 \mathrm{~mol} \mathrm{~N}$-acetylhexosamine, $2.5 \mathrm{~mol}$ alanine and I mol glutamate are present as peptidoglycan (total mol. wt about 950), then some of the walls (e.g. B. megaterium 216 and 9323) contain at least $60 \%(w / w)$ peptidoglycan. Some of the other wall preparations (e.g. strain $758 \mathrm{I}$ grown in medium A2 at $37^{\circ} \mathrm{C}$ ) contained trapped granules of poly- $\beta$-hydroxybutyrate, and hence seem to contain a lower proportion of peptidoglycan than is really present in the wall itself. In every case except $B$. cereus 7464 , LL- as well as meso- and/or DD-diaminopimelate was found. Previously, the small proportion of LL-isomer present in peptidoglycan of strain M46 was not detected, perhaps because less diaminopimelate could be loaded on to chromatograms when hydrolysates of 'sacculi' were used (White \& Gilvarg, 1977). Alanine and glutamate were the only other amino acids found (as more than traces) in any of the walls.

Since teichoic acids are, by definition, phosphorus-containing polymers, a wall with little phosphorus must also have little (if any) teichoic acid. Thus, after growth in medium AI, walls of $B$. megaterium strains $\mathrm{M}, 216,758 \mathrm{I}, 9323$ and 9376 must contain less than $0 . \mathrm{I} \mathrm{g}$ teichoic acid (assuming that $\mathrm{I}$ mol phosphate is equivalent to about $300 \mathrm{~g}$ teichoic acid) per I $g$ peptidoglycan (assuming that $\mathrm{I}$ mol Dap is equivalent to $950 \mathrm{~g}$ peptidoglycan). Teichoic acid is present in walls of $B$. megaterium $\mathrm{KM}$; whether there is teichoic acid in walls of some other strains of $B$. megaterium (e.g. 4821 and 13632) that contain more than 0.5 $\mu$ mol phosphate $(\mu \text { mol Dap })^{-1}$ is unknown.

I am grateful to Miss Lorna B. Young for her excellent technical assistance. Some of the walls were isolated by $\operatorname{Dr}$ A. Day.

\section{REFERENCES}

AMES, B. N. (1966). Assay of inorganic phosphate, total phosphate and phosphatases. Methods in Enzymology 8, $115-118$.

BADDILEY, J. (1968). Teichoic acids and the molecular structure of bacterial walls. Proceedings of the Royal Society Br7o, 33I-348.

BaIley, R. W. (1969). Carbohydrates. In Data for Biochemical Research, 2nd edn, pp. 539-550. Edited by R. M. C. Dawson, D. C. Elliott, W. H. Elliott and K. M. Jones. Oxford: University Press.

BitTer, T. \& MUIR, H. M. (I962). A modified uronic acid carbazole reaction. Analytical Biochemistry 4, 330-334.

Buchanan, R. E .\& Gibbons, N. E. (editors) (1974). Bergey's Manual of Determinative Bacteriology, 8th edn. Baltimore: Williams \& Wilkins.

CONN, H. J., JeNNISON, M. W. \& WeEKS, O. B. (1957). Routine tests for the identification of bac- teria. In Manual of Microbiological Methods, pp. I40-168. Society of American Bacteriologists. New York: McGraw-Hill.

DAY, A. \& White, P. J. (1977). Enzymic assays for isomers of 2,6-diaminopimelic acid in walls of Bacillus cereus and Bacillus megaterium. Biochemical Journal r6r, 677-685.

Dische, Z. \& Shettles, L. B. (1948). A specific color reaction of methylpentoses and a spectrophotometric micromethod for their determination. Journal of Biological Chemistry 175, 595-603.

Dubois, M., Gilles, K. A., Hamilton, J. K., Rebers, P. A. \& SMITH, F. (1956). Colorimetric method for determination of sugars and related substances. Analytical Chemistry 28, 350-356.

Ellwood, D. C. \& TeMPEST, D. W. (1972). Effects of environment on bacterial wall content and composition. Advances in Microbial Physiology 7, 83-1 17 . 
GhuYsen, J.-M., LeyH-BOUIlle, M. \& DierickX, L. (1962). Structure des parois de Bacillus megaterium KM. 2. Étude des complexes mucopeptidique et phosphomucopolysaccharidique. Biochimica et biophysica acta 63, 297-307.

Herbert, D., Phipps, R. J. \& Strange, R. E. (1971). Chemical analysis of microbial cells. Methods in Microbiology 5B, 209-344.

Milner, H. W., Lawrence, N. S. \& French, C. S. (I950). Colloidal dispersion of chloroplast material. Science III, 633-634.

Pitel, D. W. \& Gilvarg, C. (1970). Mucopeptide metabolism during growth and sporulation in Bacillus megaterium. Journal of Biological Chemistry 245, 6711-6717.

Rhuland, L. E., Work, E., Denman, R. F. \& HOARE, D. S. (1955). The behaviour of isomers of $\alpha, \epsilon$-diaminopimelic acid on paper chromato- grams. Journal of the American Chemical Society 77, 4844-4846.

SALEH, F. \& WhITE, P. J. (1976). Use of auxotrophic mutants to isolate LL- or DD-isomers of 2,6 diaminopimelic acid. Journal of General Microbiology 96, 253-26I.

WhIte, P. J. (1972). The nutrition of Bacillus megaterium and Bacillus cereus. Journal of General Microbiology 71, 505-514.

White, P. J. \& Gilvarg, C. (1977). A teichuronic acid containing rhamnose from cell walls of Bacillus megaterium. Biochemistry 16, 2428-2435.

WORK, E. (1957). Reaction of ninhydrin in acid solution with straight-chain amino acids containing two amino groups and its application to the estimation of $\alpha, \epsilon$-diaminopimelic acid. Biochemical Journal 76, 416-423. 